\title{
EFFECT OF ENFLURANE AND FENTANYL ON THE CLINICAL CHARACTERISTICS OF LONG-TERM SUCCINYLCHOLINE INFUSION
}

\author{
F. Donati and D.R. Bevan
}

\begin{abstract}
ABSTRACI
The characteristics of the neuromuscular block produced by prolonged succinylcholine infusion were compared in 40 patients anaesthetized with either nitrous oxide with enflurane (1-2 per cent inspired) or nitrous oxide and fentanyl. Neuromuscular transmission was monitored using train-of-four stimulation and the infusion rate was adjusted to keep the first twitch at $10-15$ per cent of its control value.

Initially, all patients exhibited a depolarizing-type block all twitches of the trainof-four being roughly the same size, and the infusion rates were similar in the enflurane $\left(54 \mu \mathrm{g} \cdot \mathrm{kg}^{-1} / \mathrm{min}\right)$ and the fentanyl $\left(58 \mu \mathrm{g} \cdot \mathrm{kg}^{-1} / \mathrm{min}\right)$ groups. Tachyphylaxis developed later in both groups and correlated well with the onset of phase II block (dual block). This occurred sooner and at a lower cumulative dose in the enflurane group. Fourth to first twitch ratios decreased to 50,25 and 0 per cent in 31,46 and 59 minutes in the enflurane group, at cumulative succinylcholine doses of $2.2,3.2$ and $4.2 \mathrm{mg} \cdot \mathrm{kg}^{-1}$ respectively. Corresponding figures for the fentanyl group were 52,73 and 86 minutes, with doses of 3.4, 5.0 and $5.9 \mathrm{mg} \cdot \mathrm{kg}^{-1}$. Infusion rates increased markedly after establishment of dual block, but were similar with enflurane $\left(0.99 \mathrm{mg} \cdot \mathrm{kg}^{-1} / \mathrm{min}\right)$ and fentanyl $\left(1.12 \mathrm{mg} \cdot \mathrm{kg}^{-1} / \mathrm{min}\right)$. Ten minutes after stopping the infusion fourth to first twitch ratios failed to reach 50 per cent in most patients given enflurane who had received more than $6 \mathrm{mg} \cdot \mathrm{kg}^{-1}$ succinylcholine over more than 90 minutes. Corresponding figures for fentanyl patients were $13 \mathrm{mg} \cdot \mathrm{kg}^{-1}$ and 150 minutes. The block in all 15 patients ( 9 enflurane, 6 fentanyl) who did not recover spontaneously was successfully antagonized with atropine and neostigmine.
\end{abstract}

Key Words: Neuromuscular Relaxants, succinylcholine; Pharmacology, Drug Interaction, succinylcholine, enflurane, fentanyl.

DURING PROLONGED INFUSION of succinylcholine, the characteristics of the neuromuscular blockade change from an initial depolarizing, phase I, to a non-depolarizing phase II block. ${ }^{1-3}$ Lee, et al. ${ }^{1}$ have shown that during anaesthesia with 1-2 per cent enflurane, the transition from phase I to phase II block was associated with tachyphylaxis. However, Ramsey, et al. ${ }^{2}$ demonstrated that, with nitrous oxide-narcoticthiopentone anaesthesia, tachyphylaxis was independent of the type of block.

More recently, Hilgenberg and Stoelting ${ }^{4}$ found that, using intermittent bolus injections of succinylcholine, the transition from phase I to phase II block occurred at a lower cumulative dose of succinylcholine under halothane or enflurane anaesthesia than with nitrous oxide and narcotic. However, in their study, total doses of succinylcholine were relatively small, the degree of paralysis was less than that

F. Donati, M.D., Ph.D., D.R. Bevan, M.B., M.R.C.P., F.F.A.R.C.S., Department of Anaesthesia Royal Victoria Hospital \& McGill University, 687 Pine Avenue West, Montreal, Quebec.

Can. Anaesth. Soc. J., vol. 29, no. 1, January 1982 required for intra-abdominal operations and the influence of the choice of anaesthetic agent on the recovery from succinylcholine was not studied.

The present investigation was undertaken to compare the characteristics of the neuromuscular blocks produced by a continuous infusion of succinylcholine in patients anaesthetized with either nitrous oxide-narcotic or nitrous oxideenflurane. Train-of-four stimulation was used to monitor the type, extent and recovery of neuromuscular block

\section{METHOD}

The protocol was approved by the Hospital Ethics Committee. After informed consent had been obtained 40 healthy adult patients in ASA status I or II, with no known or suspected neuromuscular, hepatic or renal disease, were assigned randomly to fentanyl-nitrous oxide or enflurane-nitrous oxide anaesthesia. Patients in both groups were premedicated with morphine, $0.1 \mathrm{mg} \cdot \mathrm{kg}^{-1}$ or meperidine $1 \mathrm{mg} \cdot \mathrm{kg}^{-1}$ and atro59 
TABLE I

Patient Data

\begin{tabular}{lcccc}
\hline \hline & & & \multicolumn{2}{c}{ Succinylcholine } \\
\cline { 4 - 5 } & $\begin{array}{c}\text { Age } \\
\text { (yrs) }\end{array}$ & $\begin{array}{c}\text { Weight } \\
(\mathrm{kg})\end{array}$ & $\begin{array}{c}\text { Duration } \\
(\mathrm{min})\end{array}$ & $\begin{array}{c}\text { Dose } \\
\left(\mathrm{mg}^{\mathrm{k}} \mathrm{kg}^{-1}\right)\end{array}$ \\
\hline $\begin{array}{l}\text { Group 1 - Fentanyl } \\
\text { (9 male, 11 female) }\end{array}$ & & & & \\
Mean & 56.0 & 68.8 & 104 & 8.4 \\
Sem & 3.6 & 2.9 & 10.3 & 1.4 \\
Range & $19-81$ & $48-96$ & $51-185$ & $2.4-23$ \\
Group 2 - Enflurane & & & & \\
(8 male, 12 female) & 55.6 & 67.6 & 97 & 7.3 \\
Mean & 3.5 & 1.8 & 13.4 & 1.0 \\
Sem & $22-77$ & $50-88$ & $40-281$ & $1.5-20$ \\
Range & & & & \\
\hline
\end{tabular}

pine $0.4-0.6 \mathrm{mg}$ intramuscularly. Anaesthesia was induced with thiopentone $3-5 \mathrm{mg} \cdot \mathrm{kg}^{-1}$, and maintained with 70 per cent nitrous oxide in oxygen. It was supplemented by enflurane, 1-2 per cent (inspired), or fentanyl $0.25 \mathrm{mg}$ after induction, followed by $0.1 \mathrm{mg}$ every thirty minutes. Tracheal intubation was done in all patients who were ventilated to maintain normocapnia. ${ }^{5}$ Blood pressure and electrocardiogram were recorded in all cases.

Neuromuscular transmission was monitored according to the method of Ali, et al. ${ }^{6}$ The ulnar nerve was stimulated supramaximally at the elbow using subcutaneous needle electrodes. Trains-of-four with square pulses of $0.2 \mathrm{~ms}$ duration at a frequency of $2 \mathrm{~Hz}$ and a train duration of $2 \mathrm{~s}$ were repeated every $10 \mathrm{~s}$ using a Grass \$48 stimulator and a SIUS Isolation Unit. The hand and forearm were immobilized in a splint and the force of adduction of the adductor pollicis was measured with a force-displacement transducer (Grass F.T. 10) and recorded using a pen and ink recorder (grass Polygraph).

After a stable baseline had been obtained, a succinylcholine infusion ( 0.5 per cent) was started using an infusion pump (IVAC), at a rate of $10-15 \mathrm{mg} / \mathrm{min}$. When the twitch response had disappeared completely, the infusion rate was decreased, and the trachea was intubated. The infusion rate of succinylcholine was then adjusted to keep the first twitch of the train-of-four at 10-15 per cent of its pre-infusion value. The infusion was stopped a few minutes before the anticipated termination of the operation and the neuromuscular junction was allowed to recover spontaneously for 10 minutes. The train-of-four ratio, $T_{4} / T_{1}$, the ratio of the force of the 4 th twitch to the force of the first twitch in each train, was then measured and neostigmine 1.25 $2.5 \mathrm{mg}$ was given with atropine $0.6-1.2 \mathrm{mg}$ to patients whose $T_{4} / T_{1}$ ratio was less than 50 per cent.

Infusion rates were calculated for every tenminute period after the start of the infusion, and train-of-four ratios were measured at the end of each period.

The mean values are presented with the standard error of the mean as the index of dispersion. Probabilities were calculated from Student's t test for unpaired data where appropriate and the null hypothesis was rejected when $\mathrm{P}<0.05$. Regression lines were constructed by the least squares regression method.

\section{RESULTS}

Both groups of patients were comparable with respect to age, sex, weight, duration of infusion and total dose of succinylcholine given (Table I).

\section{Infusion Rates}

The mean succinylcholine infusion rates were similar in both groups (Figure 1). Succinylcholine requirements decreased after the first ten minute period because a loading dose was given initially whilst only maintenance doses were administered subsequently. However, it was necessary to increase the infusion rates progressively to maintain a 90 per cent block: after 90 minutes, they were $75-80$ per cent higher than at 20 minutes. This increase tended to occur sooner in patients who were given enflurane. 


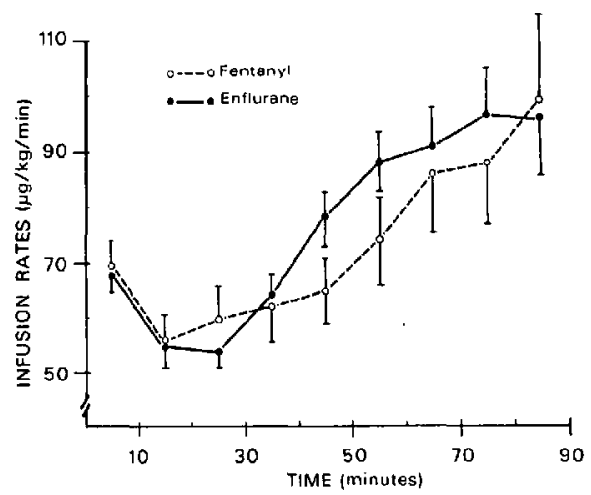

FIGURE 1 Infusion rates of succinylcholine required to maintain 90 per cent block, in patients anaesthetized with fentanyl-nitrous oxide or enflurane-nitrous oxide.

\section{Characteristics of the Block}

During the first few minutes after the start of the infusion the $T_{4} / T_{1}$ was close to unity in all patients. After a variable time $\mathrm{T}_{4} / \mathrm{T}_{1}$ decreased gradually and this fade tended to occur sooner and to develop more rapidly in patients receiving enflurane (Figure 2). Half the patients developed a $T_{4} / T_{1}$ of 50 per cent in 31 minutes, of 25 per cent in 46 minutes and 0 per cent in 59 minutes, whereas patients anaesthetized with fentanyl required 52, 73 and 86 minutes respectively to achieve the same ratios (Figure 3 ). These differences were statistically significant (Figure 3 ) in spite of considerable individual variation, especially in the fentanyl group.

The cumulative succinylcholine doses required to achieve a given degree of train-offour fade were also smaller in the enflurane group (Figure 4 ). The doses producing $T_{4} / T_{1}$ of 50,25 and 0 per cent in half the patients $\left(\mathrm{ED}_{50}\right)$ were $2.2,3.2$ and $4.2 \mathrm{mg} \cdot \mathrm{kg}^{-1}$ respectively in patients who received enflurane and 3.4, 5.0 and $5.9 \mathrm{mg} \cdot \mathrm{kg}^{-1}$ in patients anaethetized with fentanyl (Figure 5). These differences between the two groups were statistically significant.

\section{Infusion Rate and Train-of-Four Fade}

The relationship between infusion rates and the development of phase II block was examined by including the fade of the second twitch $\left(T_{2} / T_{1}\right)$ as well as of the fourth twitch $\left(T_{4} / T_{1}\right)$. This enabled a larger span of the fade phenomenon to be studied. Decreases of $T_{4} / T_{1}$ and $T_{2} T_{1}$ were associated with increasing infusion rates,

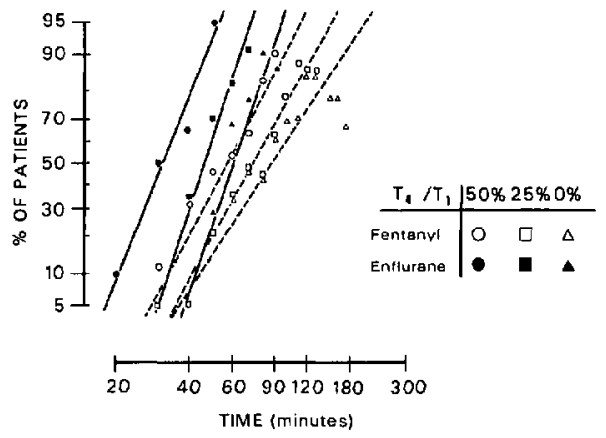

FIGURE 2 Cumulative percentage of patients demonstrating train-of-four ratios $\left(\mathrm{T}_{4} / \mathrm{T}_{1}\right)$ of $0.5,0.25$ and 0 as a function of time, with fentanyl-nitrous oxide or enflurane-nitrous oxide anaesthesia.

- Fentanyl

- Enflurane

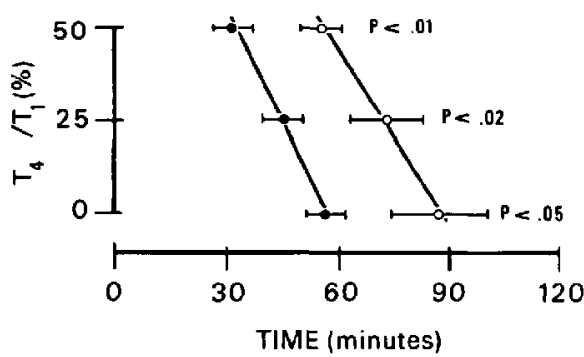

FIgURE 3 Train-of-four ratio $\left(\mathrm{T}_{4} / \mathrm{T}_{1}\right)$ versus time at which half the patients developed $\mathrm{T}_{4} / \mathrm{T}_{1}$ of $0.5,0.25$ and 0 , with fentanyl-nitrous oxide and enfluranenitrous oxide anaesthesia.

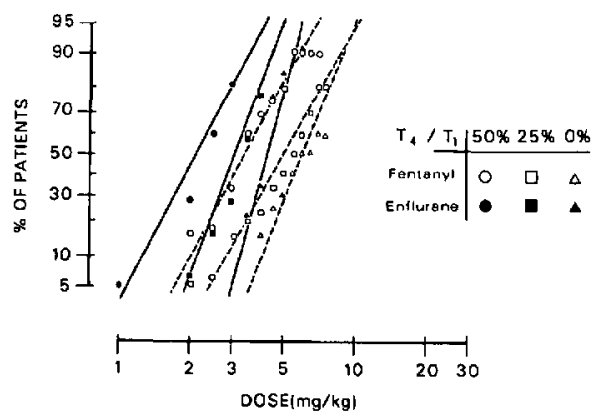

FIGURE 4 Cumulative percentage of patients dem. monstrating train-of-four ratios $\left(T_{4} / T_{1}\right)$ of 50,25 and 0 per cent as a function of succinylcholine dose given with fentanyl-nitrous oxide or enflurane-nitrous oxide anaesthesia. 
and this relationship was independent of the choice of anaesthesia (Figure 6). When the second twitch disappeared $\left(T_{2} / T_{1}\right)=0$ ), the mean succinylcholine infusion rates were 81 and 78 per cent higher than control values, i.e. infusion rates between 10 and 30 minutes after the infusion had been started. Although the range of values was large (41-153 per cent), all patients exhibited an increase in infusion rate. Furthermore, all showed a gradual increase in infusion rate with decreasing $T_{2} / T_{1}$.

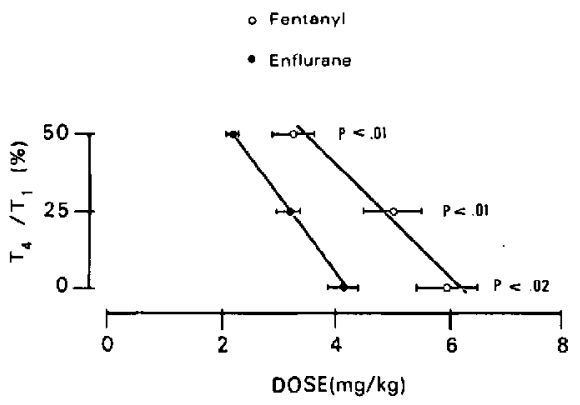

Figure 5 Train-of-four ratio versus dose at which half the patients developed $T_{4} T_{1}$ of $0.5,0.25$ and 0 with fentanyl-nitrous oxide and enflurane-nitrous oxide anaesthesia.

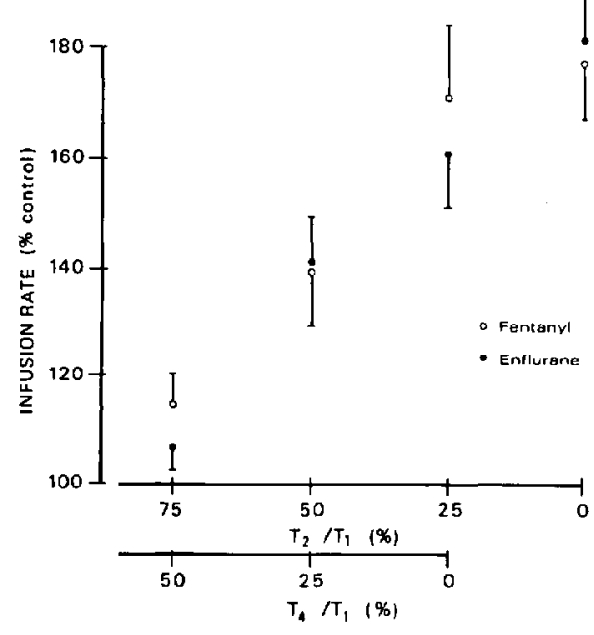

FIGURE 6 Infusion rates necessary to keep the first twitch of a train-of-four at 10 per cent of its preinfusion value, expressed as a percentage of infusion rate between 10 and 30 minutes after the start of the infusion, versus the ratio of the second to the first twitch $\left(T_{2} / T_{1}\right)$ and the ratio of the fourth to the first twitch $\left(\mathrm{T}_{4} / \mathrm{T}_{1}\right)$.

\section{Recovery}

After 10 minutes of spontaneous recovery $T_{4} / T_{1}$ was inversely related to the duration of the succinylcholine infusion and the total dose given. $T_{4} / T_{1}$ was decreased more during enflurane than fentanyl anaesthesia. Mean duration of succinylcholine infusion for a $T_{4} / T_{1}$ recovery to 50 per cent was 88 minutes for enflurane and 150 minutes for fentanyl anaesthesia, and total doses were 6.6 and $13 \mathrm{mg} \cdot \mathrm{kg}^{-1}$ respectively. Although $\mathrm{T}_{4} / \mathrm{T}_{1}$ correlated well with duration $(\mathrm{r}=0.85$ and $0.84)$ and total dose ( $r=0.89$ and 0.88$)$, the correlations were better with the duration-dose product ( $r=0.91$ and 0.90 ) (Figure 7) for both fentanyl and enflurane anaesthesia. All patients (9 - enflurane, 6 - fentanyl) who exhibited a $\mathrm{T}_{4} / \mathrm{T}_{1}$ of less than 50 per cent after 10 minutes of spontaneous recovery were given neostigmine $(1.25-2.5 \mathrm{mg})$ and this produced rapid recovery of the neuromuscular junction to the point where $\mathrm{T}_{4} / \mathrm{T}_{1}$ exceeded 0.7 .

\section{Discussion}

Previous studies ${ }^{7,8}$ have shown that enflurane potentiates the action of d-tubocurarine and pancuronium, but does not affect either the intensity of duration of action of succinylcholine administered by bolus injections, ${ }^{4,8,10}$ In the present investigation the rates of infusion required to maintain 80-90 per cent blocks did not differ between the enflurane and narcotic groups. Thus enflurane did not alter the potency

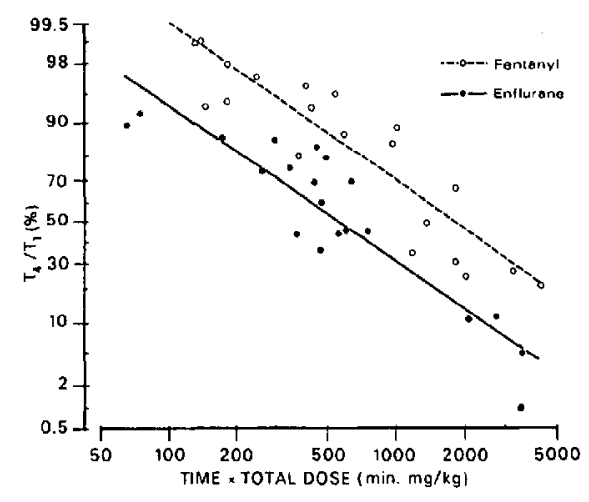

FiguRE $7 \quad T_{4} T_{1}$ after 10 minutes recovery versus the product of total time of succinylcholine infusion and cumulative dose given in patients receiving fentanyl $(r=0.91)$ and enflurane $(r=0.90)$. 
of succinylcholine either early in the course of the infusion, when the block was predominantly depolarizing, or later when non-depolarizing block had developed. The rates of infusion increased with time in both groups indicating that tachyphylaxis occurred with both anaesthetic techniques.

The main effect of enflurane on the succinylcholine block was a significant acceleration of the development of non-depolarizing (phase II) block, characterized by an increasing train-offour fade. This explains the difference between Lee, et al. ${ }^{1}$ who found a rapid "transition of phases" with enflurane-nitrous oxide anaesthesia and Ramsey, et al., ${ }^{2}$ who demonstrated a rather slow and unpredictable onset of phase II block under narcotic-nitrous oxide anaesthesia. Our results also agree with those of Hilgenberg and Stoelting, ${ }^{4}$ who reported that a $T_{4} T_{1}$ of 50 per cent was reached with a lower cumulative dose of succinylcholine during enflurane (4.4 $\left.\mathrm{mg} \cdot \mathrm{kg}^{-1}\right)$ than fentanyl $\left(6.4 \mathrm{mg} \cdot \mathrm{kg}^{-1}\right)$ anaesthesia. Their values were higher than ours (2.2 and $3.4 \mathrm{mg} \cdot \mathrm{kg}^{-1}$ ) respectively, but in the present study $T_{4} / T_{1}$ was measured at 90 per cent block whereas they measured $T_{4} / T_{1}$ at $60-70$ per cent block. The depth of neuromuscular block clearly affects $T_{4} / T_{1}^{9}$ and this may explain why $T_{4} / T_{1}$ never stabilized, in our study, at a non-zero value, as reported by other investigators $1,4,10$ who measured $T_{4} / T_{1}$ at a lower degree of neuromuscular block.

It has been observed qualitatively that the change from phase I to phase II block was associated with an increase in succinylcholine requirements ${ }^{1,3}$ during inhalational anaesthesia, although with narcotic-nitrous oxide anaesthesia the relationship has been disputed. ${ }^{2}$ In part, the controversy is a result of differing definitions of tachyphylaxis. As shown in Figure 1, the process by which more succinylcholine is needed with time (tachyphylaxis), is not discrete but continuous, and has wide individual variation. Tachyphylaxis and the onset of phase II block seemed to be delayed with narcotic anaesthesia. When compared with train-of-four fade (Figure 6 ), infusion rates were directly related to the degree of phase II block, and this relationship was not affected by enflurane. Although no causal relationship can be proved in this case, these results show a close association of phase II (dual) block and tachyphylaxis, both with enflurane and fentanyl anaesthesia.

The rate of recovery of train-of-four fade was related to the total dose of succinylcholine and the duration of administration. In addition, recovery was delayed during enflurane anaesthesia so that with nitrous oxide-fentanyl anaesthesia the same $T_{4} / T_{1}$ was achieved with twice the dose of succinylcholine as in the enflurane group. However, those 15 patients who had not recovered a $T_{4} / T_{1}$ of 50 per cent within 10 minutes of stopping the infusion, all recovered rapidly after neostigmine whether they had been given fentanyl or enflurane. Thus, a nondepolarizing type of block produced by succinylcholine is readily reversible with anticholinesterases. ${ }^{11}$

Clinically, succinylcholine infusion with careful neuromuscular monitoring is a useful relaxant technique. The depth of the block can be altered rapidly; good surgical relaxation can be achieved and recovery is rapid even when large doses $(1-2 \mathrm{~g})$ have been administered. Although phase II block appears earlier with enflurane than with fentanyl anaesthesia, either agent can be used with succinylcholine, and no limit for the total dose of succinylcholine need be advocated because phase II block is rapidly antagonized with neostigmine.

\section{REFERENCES}

1. LeE, C., Barnes, A. \& Katz, R.L. Magnitude, dose-requirement and mode of development of tachyphylaxis to suxamethonium in man. Br. J. Anaesth., 50: 189, (1978).

2. Ramsey, F.M., Lebowitz, P.W., Savarese, J.J. \& ALI, H.H. Clinical characteristics of long-term succinylcholine neuromuscular blockade during balanced anaesthesia. Anesth. Analg. 59: $110(1980)$.

3. LEE, C. Dose relationships of phase II, tachyphylaxis and train-of-four fade in suxamethoniuminduced dual neuromuscular block in man. $\mathrm{Br}$. J. Anaesth., 47: 841 (1975).

4. Hilgenberg, J.C. \& Stoelting, R.K. Characteristics of succinylcholine-produced phase II neuromuscular block during enflurane, halothane, and fentanyl anesthesia. Anesth. Analg., 60: 192 (1981)

5. Bain, J.A. \& Sroerel, W.E. Flow requirements for a modified Mapleson D system during controlled ventilation. Can. Anaesth. Soc. J. 20:629 (1973).

6. Alli, H.H., Utting, J.E. \& Gray, C. Stimulus frequency in the detection of neuromuscular block in humans. Br. J. Anaesth. 42: 967 (1970).

7. FogDall, R.P. \& Miller, R.D. Neuromuscular effects of enflurane, alone and combined with d-tubocurarine, pancuronium, and succinylcholine, in man. Anesthesiology, 42, 173 (1975). 
8. Lebowitz, M.H., Britt, C.D. \& Walts, L.F. Depression of twitch response to stimulation of the ulnar nerve during ethrane anesthesia in man. Anesthesiology, 33: 52 (1970).

9. LEE, C. \& KATZ, R.L. Neuromuscular pharmacology: a clinical update and commentary. Br. J. Anaesth. 52: 173 (1980).
10. LEE, C. Dose relationships of phase II, tachyphylaxis and train-of-four fade in suxamethonium-induced dual neuromuscular block in man. Br. J. Anaesth., 47: 841 (1975).

11. LEE, C. Train-of-four fade and edrophonium antagonism of neuromuscular block by succinylcholine in man. Anesth. Analg., 55: 663 (1976).

\section{RÉSUMÉ}

Les caractéristiques du blocage neuromusculaire produit par la perfusion de longue durée de succinylcholine ont été comparées sur 40 patients anesthésiés soit au protoxyde d'azote-enflurane (concentration inspirée 1-2 pour cent) soit au protoxyde d'azotefentanyl. La transmission neuromusculaire a été monitorée par la séquence de quatre stimulations et la vitesse de perfusion réglée pour obtenir une contraction à $10-15$ pour cent de la valeur de contrôle.

Au départ, tous les patients ont montré un bloc dépolarisant; toutes les contractions de la séquence de même amplitude et la vitesse d'infusion était sensiblement la même pour les deux groupes: enflurane $\left(54 \mu \mathrm{g} \cdot \mathrm{kg}^{-1} / \mathrm{min}\right)$ et fentanyl $\left(58 \mu \mathrm{g} \cdot \mathrm{kg}^{-1} / \mathrm{min}\right)$. Plus tard la tachyphylaxie est apparue dans les deux groupes en même temps que l'apparition du bloc de phase II (bloc double). Ce phénomène est apparu plus tôt et à une dose cumulative inférieure dans le groupe enflurane. Le rapport entre la quatrième et la première contraction a diminué à 50,25 et 0 pour cent en 31,46 et 59 minutes dans le groupe enflurane à des doses cumulatives respectives de $2.2,3.2 \mathrm{et} 4.2 \mathrm{mg} \cdot \mathrm{kg}^{-1}$. Les chiffres correspondants pour le fentanyl étaient de 52,73 et 86 minutes, avec des doses de $3.4,5.0$ et $5.9 \mathrm{mg} \cdot \mathrm{kg}^{-1}$. Les vitesses d'infusion ont augmenté de façon importante une fois le bloc double établi mais étaient identiques avec l'enflurane $\left(0.99 \mathrm{mg} \cdot \mathrm{kg}^{-1} / \mathrm{min}\right.$.) et le fentanyl $\left(1.12 \mathrm{mg} \cdot \mathrm{kg}^{-1} / \mathrm{min}\right.$.). Dix minutes après l'arrêt de la perfusion, le rapport entre la quatrième et la première contraction n'a pas atteint 50 pour cent pour la plupart des patients sous enflurane dont la dose de succinylcholine avait dépassé $6 \mathrm{mg} \cdot \mathrm{kg}^{-1}$ administrée sur plus de 90 minutes. Les chiffres correspondant pour le fentanyl étaient de $13 \mathrm{mg} \cdot \mathrm{kg}^{-1}$ sur 150 minutes. Le bloc neuromusculaire observé chez 15 patients ( 9 enflurane, 6 fentanyl) qui n'ont pas récupéré spontanément a été renversé avec succès par l'association atropine-néostigmine. 